University for Business and Technology in Kosovo

UBT Knowledge Center

UBT International Conference

2017 UBT International Conference

Oct 28th, 11:00 AM - 12:30 PM

\title{
Quality and safety of vegetables based on nitrogen determination and intake
}

\author{
Mariola Kodra \\ Agricultural University of Tirana, mkodra@ubt.edu.al \\ Ariola Devolli \\ Agricultural University of Tirana \\ Edlira Shahinasi \\ Agricultural University of Tirana \\ Dhurata Feta \\ Agricultural University of Tirana
}

Follow this and additional works at: https://knowledgecenter.ubt-uni.net/conference

Part of the Food Science Commons

\begin{abstract}
Recommended Citation
Kodra, Mariola; Devolli, Ariola; Shahinasi, Edlira; and Feta, Dhurata, "Quality and safety of vegetables based on nitrogen determination and intake" (2017). UBT International Conference. 161.

https://knowledgecenter.ubt-uni.net/conference/2017/all-events/161

This Event is brought to you for free and open access by the Publication and Journals at UBT Knowledge Center. It has been accepted for inclusion in UBT International Conference by an authorized administrator of UBT Knowledge Center. For more information, please contact knowledge.center@ubt-uni.net.
\end{abstract}




\title{
Quality and safetv of vegeteables based on nitrogen determation and intake
}

\author{
Mariola KODRA $^{1}$, Ariola DEVOLLI ${ }^{1}$, Edlira SHAHINASI ${ }^{1}$, Dhurata FETA ${ }^{1}$ \\ ${ }^{1}$ Agricultural University of Tirana, Faculty of Biotechnology and Food, Chemistry \\ Departament \\ Mariola Kodra, \\ mkodra@ubt.edu.al
}

\begin{abstract}
Vegetables are one of the main sources of nitrogen on human diet. Nitrogen content in 30 soil samples and 30 vegetables samples are reported. The results indicate that nitrogen content was low in $33 \%$ of soil samples, normal in $50 \%$ of the samples, and high in $17 \%$ of soil samples. Reported results indicate that $47 \%$ of vegetables samples had low nitrogen content, $30 \%$ of them had normal nitrogen content, and $13 \%$ and $10 \%$ of them had high and very high nitrogen content, respectively. Soil nitrogen is also reported as ammonium and nitrate, and results indicate that nitrate is the dominant form of nitrogen. There was a good correlation between soil nitrogen and vegetables nitrogen, of $R^{2}=0.91$, and also between nitrate and ammonium in soil and vegetables nitrogen.
\end{abstract}

Keywords: quality, safety, vegetables, nitrogen, intake.

\section{INTRODUCTION}

Nitrogen is one of the most widespread elements comprising about $80 \%$ of Soil atmosphere. It is an important element of plant tissues constituting proteins, nucleoproteins, hemoglobin, nucleic acids, chlorophyll and other molecular molecules, and it is supposed that it comprise $3 \%$ human body weight and $4 \%$ of plants dry matter. Nitrogen can be present in different inorganic and organic forms, part of nitrogen cycle, like ammonium, nitrate and nitrite, and all these forms play an important role in vegetables production, their quality and safety as well as in food chain. Our study has been focused on nitrogen because of its highest effect on soil quality when compared to other plants nutrients. The aim of this study was to determine $\mathrm{N}$ content on a glasshouse soil, of both two forms ammonium and nitrate, and then determination of $\mathrm{N}$ content in vegetables planted to see if there was any link between soil nitrogen and vegetables nitrogen. This paper also deals sources of nitrogen in humans diets pointing out some problems related to its toxicity and daily intake links. Because of their cumulative properties, nitrates are an important part of vegetables [1].

\section{SOURCES AND TOXICITY OF NITROGEN FORMS}

Nitrogen is one of the nutrient that may limit vegetables growth and production, and for this reason farmes usully abuse in using nitrogen fertilizers. Main sources of nitrogen are inorganic and organic fertilizers, plant residues and soil organic matter. Use of inorganic nitrogen fertilizers has growth within the last decades (for economin reasons to grow vegetables yields) and this has been in focus of many scientist for studing the levels of nitrogen content in vegetables and its daily intake limits. Absorption of nitrate occurs most often from natural sources, but vegetables 
accumulate a significant portion of nitrate from nitrogen-based fertilizers, which are used for fertilizing plants for faster and bigger growth [2]. Leafy vegetables, such as lettuce or spinach, contain the highest concentrations of nitrate [3]. Higher levels of nitrate tend to be found in leaves whereas lower levels occur in seeds or tubers, thus leaf crops such as lettuce and spinach generally have higher nitrate concentrations [4]. Approximately $80 \%$ of dietary nitrates are derived from vegetable consumption [5]. Sources of nitrites include vegetables, fruit, and processed meats, which means that human exposure to nitrate is usually associated with intake through vegetables, and to a lesser extent, with other foods and water [6]. Due to the increased use of synthetic nitrogen fertilizers and livestock manure in intensive agriculture, vegetables and drinking water may contain higher concentrations of nitrate [4]. The presence of nitrate in vegetables as well as in water and other food may be of serious risk. Nitrate per se is relatively non-toxic, but its metabolites and reaction products e.g., nitrite, nitric oxide and N-nitroso compounds, have raised concern because of implications for adverse health effects such as methaemoglobinaemia and carcinogenesis [4]. The only chronic toxic effects of nitrate are those resulting from the nitrite formed by its reduction by bacterial enzymes [7].

The best-known effect of nitrite is its ability to react with hemoglobin (oxyHb) to form methaemoglobin (metHb) and nitrate: $\mathrm{NO}_{2}^{-}+$oxyHbFe$\left.{ }^{2+}\right) \rightarrow$ metHb $\left(\mathrm{Fe}^{3+}\right)+\mathrm{NO}_{3}-$

As a consequence of the formation of metHb the oxygen delivery to tissue is impaired. Once the proportion of metHb reaches $10 \%$ of normal $\mathrm{Hb}$ levels, clinical symptoms (from cyanosis - the blue discoloration of the skin due to the presence of deoxygenated bloodthrough to asphyxia-suffocation) occur and this potentially fatal condition is known as methaemoglobinaemia, or blue baby syndrome. [8].

Nitrite as such, and nitrate when reduced to nitrite, may react with amines or amides to form carcinogenic $N$-nitroso compounds. Nitrosation can occur mainly in two situations: (1) during storage and ripening of the food product and (2) in the stomach from the action of salivary nitrite produced through enzymatic reduction of endogenous or exogenous nitrate. [9].

Recent research suggests that dietary nitrate may have beneficial effects; based on the hypothesis that nitric oxide (NO) formed in the stomach from dietary nitrate has antimicrobial effects on gut pathogens and a role in host defense. [10].

In another study it has been explained the physiologic context for potential health benefits suggesting that dietary nitrate, derived primarily from vegetables, could contribute to cardiovascular health via effects on nitric oxide (NO) status beacause NO plays an essential role in cardiovascular health. [11].

\section{ACCEPTABLE DAILY INTAKE (ADI)}

Human exposure to nitrate is mainly exogenous through the consumption of vegetables, and to a lesser extent water and other foods. [4]. The concept of ADI is defined by the Joint Expert Committee of the Food and Agriculture (JECFA) Organization of the United Nations/World Health Organization (WHO) for substances intentionally added to food or for contaminants (pesticides, herbicides and fertilizers). [12].

Acceptable daily intake (ADI) for nitrate was determined by the Scientific Committee on Food (SCF) in 2002 and amounts from 0 to $3.7 \mathrm{mg} / \mathrm{kg}$ body weight/day, which is equivalent to the intake of $222 \mathrm{mg}$ nitrate/day for an adult weighing $60 \mathrm{~kg}$. Studies haven shown that an adult daily consumes approximately $400 \mathrm{~g}$ of various vegetables, from which it can be concluded that the average intake of nitrate is $157 \mathrm{mg} /$ day [13]. 
Table 1. Estimated intakes of $\mathrm{NO}_{3}$ from sources other than food additives at the global level (after Hambridge [14])

\begin{tabular}{|c|c|c|c|c|c|c|}
\hline \multirow[t]{2}{*}{ Regional diet } & \multirow[t]{2}{*}{$\begin{array}{l}\text { Intake } \\
\left(\mathrm{mg} \mathrm{day}^{-1}\right)\end{array}$} & \multirow[t]{2}{*}{$\begin{array}{l}\mathrm{ADI}^{\mathrm{a}} \\
\left(\mu \mathrm{g} \mathrm{mg}^{-1}\right)\end{array}$} & \multicolumn{4}{|c|}{$\begin{array}{l}\text { Major contributors to total intake } \\
\qquad\left(\mu \mathrm{g} \mathrm{mg}^{-1}\right)\end{array}$} \\
\hline & & & Vegetables & Water & Cereals & Fruits \\
\hline Middle Eastern & 40 & 200 & 650 & 200 & 100 & 50 \\
\hline Far Eastern & 28 & 100 & 450 & 300 & 150 & 100 \\
\hline African & 20 & 100 & 300 & 400 & 150 & 100 \\
\hline Latin American & 55 & 250 & 650 & 150 & 50 & 100 \\
\hline Europian & 155 & 700 & 900 & 50 & $<50$ & 50 \\
\hline
\end{tabular}

${ }^{\mathrm{a}}$ Based on $60 \mathrm{~kg}$ body weight.

In order to protect public health regarding nitrate levels in food, in 1997 the European Member States agreed an EC Regulation setting limits for nitrate in lettuce and spinach (EC Regulation No. 194/97). The main purpose of this EC Regulation was to harmonize limits for nitrate in these vegetables because the different national limits set by some Member States were causing trade difficulties across the European Union. On April 2002 the EC amended EC Regulation No. 194/97 and adopted EC Regulation No. 563/2002. The limits of nitrate levels in this regulation vary according to season, with higher nitrate levels permitted in crops grown in winter compared with those grown in the summer.

\section{MATERIAL AND METHODS}

In this study we determined nitrogen content, of ammonium and nitrate forms, in a glasshouses soil, as well as nitrogen content in vegetables planted in these soils. Nitrogen determination was conducted by Kjeldahl method. Nitrogen was determined in 30 soil and vegetables samples.

\section{RESULTS AND DISCUSSION}

The aim of this study was to determine nitrogen content in soil and vegetable and to see if there was any correlation between nitrogen content in soil and that of vegetables. The analyzed soil samples were taken from three parcels before they were planted with vegetables. The soils were analyzed for the two forms of nitrogen, ammonium and nitrate, measured as $\mathrm{mg} / 100 \mathrm{~g}$ soil. The obtained results are shown in Table 2. 
Table 2. Results of ammonium and nitrate content in soil samples

\begin{tabular}{|c|c|c|c|c|c|c|c|c|c|c|}
\hline \multirow{4}{*}{$\begin{array}{l}\text { Soil that } \\
\text { will } \\
\text { planted } \\
\text { with } \\
\text { tomato }\end{array}$} & \multicolumn{10}{|c|}{$\mathrm{NH}_{4}{ }^{+} \mathrm{mg} / 100 \mathrm{~g}$ soil } \\
\hline & 0.42 & 0.84 & 1.12 & 0.14 & 0.19 & 1.12 & 3.11 & 0.22 & 3.73 & 1.49 \\
\hline & \multicolumn{10}{|c|}{$\mathrm{NO}_{3}^{-} \mathrm{mg} / 100 \mathrm{~g}$ soil } \\
\hline & 1.4 & 0.56 & 4.76 & 2.94 & 2.52 & 2.56 & 3.39 & 1.53 & 4.17 & 4.37 \\
\hline \multirow{4}{*}{$\begin{array}{l}\text { Soil that } \\
\text { will } \\
\text { planted } \\
\text { with } \\
\text { cucumber }\end{array}$} & \multicolumn{10}{|c|}{$\mathrm{NH}_{4}{ }^{+} \mathrm{mg} / 100 \mathrm{~g}$ soil } \\
\hline & 0.056 & 0.084 & 0.14 & 0.84 & 0.7 & 0.12 & 3.9 & 2.06 & 1.06 & 3.15 \\
\hline & \multicolumn{10}{|c|}{$\mathrm{NO}_{3}^{-} \mathrm{mg} / 100 \mathrm{~g}$ soil } \\
\hline & 0.28 & 0.28 & 0.84 & 6.16 & 9.52 & 3.24 & 7.4 & 3.18 & 3.64 & 5.35 \\
\hline Soil that & \multicolumn{10}{|c|}{$\mathrm{NH}_{4}{ }^{+} \mathrm{mg} / 100 \mathrm{~g}$ soil } \\
\hline will & 1.12 & 1.18 & 0.12 & 2.68 & 3.44 & 2.21 & 4.63 & 2.12 & 0.68 & 1.04 \\
\hline planted & \multicolumn{10}{|c|}{$\mathrm{NO}_{3}^{-} \mathrm{mg} / 100 \mathrm{~g}$ soil } \\
\hline pepper & 0.28 & 0.48 & 0.84 & 4.16 & 6.52 & 4.26 & 7.12 & 4.49 & 1.22 & 2.51 \\
\hline
\end{tabular}

We can see that content of these two forms of nitrogen is rather normal with values less than 5 $\mathrm{mg} / 100 \mathrm{~g}$ soil for nitrate. But there are also cases where the nitrate content reaches over $5 \mathrm{mg} / 100$ soil, that can be consider as a high value. When we compared the content of these nitrogen forms, it was clear that nitrate forms were the dominant one at minimum, average and maximal values for each soil parcel (Figure 1).

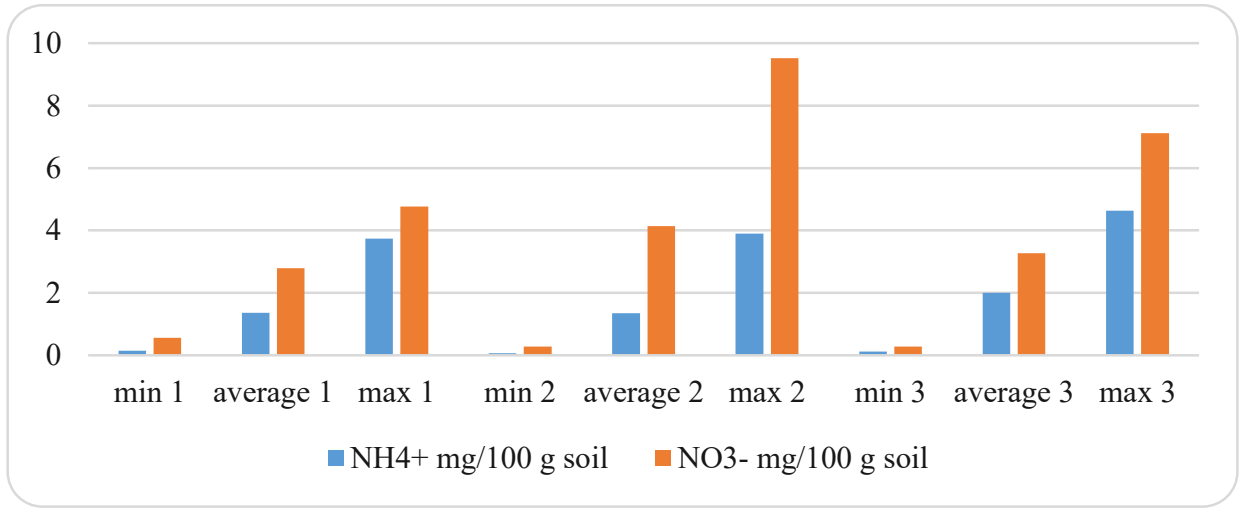

Figure 1. Comparison of ammonium and nitrate content in soil samples.

In Table 3 are shown the resulsts of total $\mathrm{N}$ content in soil. We can see that soil that is going to be planted with tomato has normal content of $\mathrm{N}$, with few values ove $5 \mathrm{mg} / 100 \mathrm{~g}$ soil. But this is not the case of soils that are going to be planted with cucumber and pepper. They may have some values of low $\mathrm{N}$ content, of less that $1 \mathrm{mg} / 100$ soil, but there were also cases of high levels of $\mathrm{N}$ content, of over $5 \mathrm{mg} / 100 \mathrm{~g}$ soil. 
Table 3. Total $\mathrm{N}$ content in soils samples

\begin{tabular}{l|cccccccccc}
\hline \multicolumn{1}{c}{ Soil that will be planted with tomato } \\
\hline Total N & 1.82 & 1.4 & 5.88 & 3.08 & 2.71 & 3.68 & 7.5 & 1.75 & 8.9 & 5.86 \\
\hline \multicolumn{10}{|c}{ Soil that will be planted with cucumber } \\
\hline Total N & 0.336 & 0.364 & 0.98 & 7 & 10.22 & 3.36 & 11.3 & 5.24 & 4.7 & 9.5 \\
\hline \multicolumn{8}{|c}{ Soil that will be planted with pepper } \\
\hline Total N & 1.4 & 1.66 & 0.96 & 6.84 & 9.96 & 6.47 & 11.7 & 6.5 & 1.9 & 3.55 \\
\hline
\end{tabular}

After evaluated each value of nitrogen content in soil we made a soil evaluation according to $\mathrm{N}$, as shown below in Figure 2, where most of the cases are evaluated as low and normal or average (in total $77 \%$ ), and only $23 \%$ of them as soil with high $\mathrm{N}$ content.

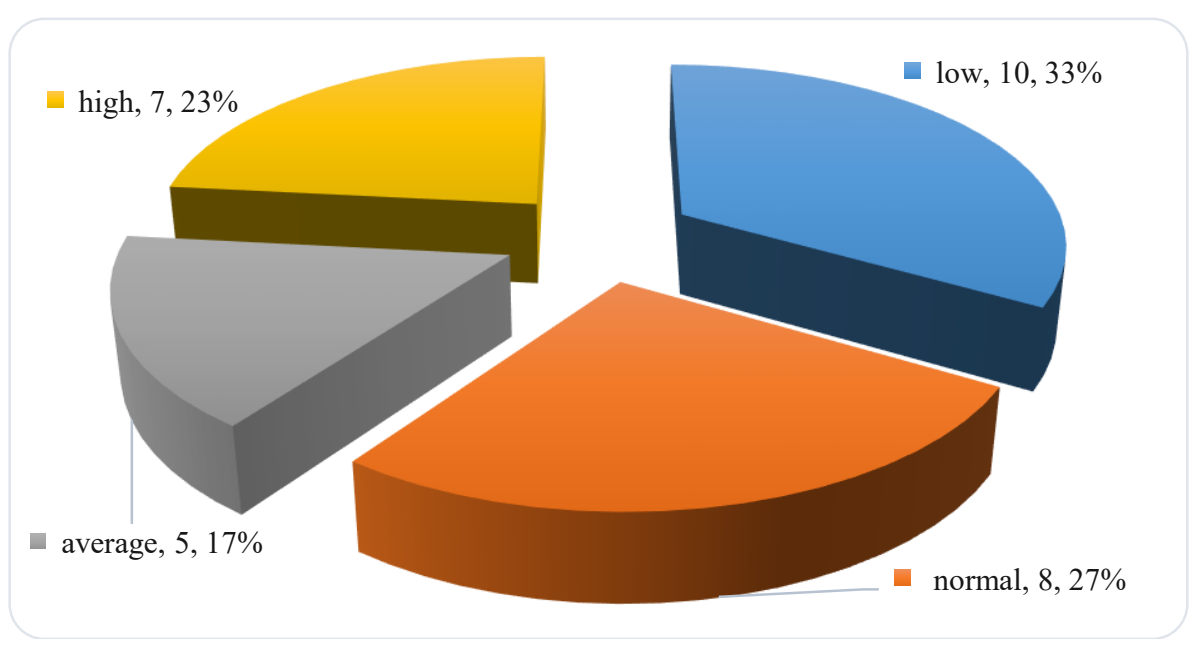

Figure 2. Soil evaluation according to total $\mathrm{N}$ content.

Nitrogen conten of soils with be reflected in nitrogen content of vegetables that will be planted, keeping in mind that soils were not treated with fertilizers when ananlysed. Nitrogen content in tomatoes fruits were generally low, less than 2-3,5\% that this vegetable need for a normal growth. Nitrogen content in cucumber fruits were generally normal, accomplaing this vegetable needs for $\mathrm{N}$ of $2-5 \%$. In this case, high nitrogen content in soil has been compensed by the high needs of this vegetable for $\mathrm{N}$. But this was not the case for $\mathrm{N}$ content in pepper fruits, because of the low needs that this vegetables has for $\mathrm{N}$, of 2-3.5\% N, and where the cases of high levels of $\mathrm{N}$ in soils have caused cases of high $\mathrm{N}$ content in fruits.

Table 4. Nitrogen (\%) content in planted vegetables.

\begin{tabular}{cccccccccc}
\hline \multicolumn{7}{c}{ Nitrogen (\%) content in tomatoes fruits } \\
\hline 1.12 & 1.96 & 2.85 & 1.87 & 1.47 & 2.4 & 2.12 & 1.18 & 4.49 & 3.85 \\
\hline \multicolumn{7}{c}{ Nitrogen (\%) content in cucumbers fruits } \\
\hline 0.9 & 1.12 & 1.32 & 4.08 & 4.24 & 2.67 & 5.65 & 1.77 & 1.64 & 5.5 \\
\hline \multicolumn{7}{c}{ Nitrogen $(\%)$} & content in pepper fruits \\
\hline 1.08 & 3.4 & 1.64 & 2.96 & 2.94 & 4.38 & 3.85 & 4.6 & 1.76 & 2.68 \\
\hline
\end{tabular}


After evaluated each value of $\mathrm{N}$ content in vegetables fruits, we can see that most of a cases are evaluated as deficiency of $\mathrm{N}(43 \%)$, and this because most of the analysed soils had low $\mathrm{N}$ content. We can also see that $30 \%$ of the cases had a normal $\mathrm{N}$ content but we must mentioned that there are also cases of high and even toxic $\mathrm{N}$ content (above vegetables needs), respectivly $17 \%$ and $10 \%$.

toxic, $3,10 \%$

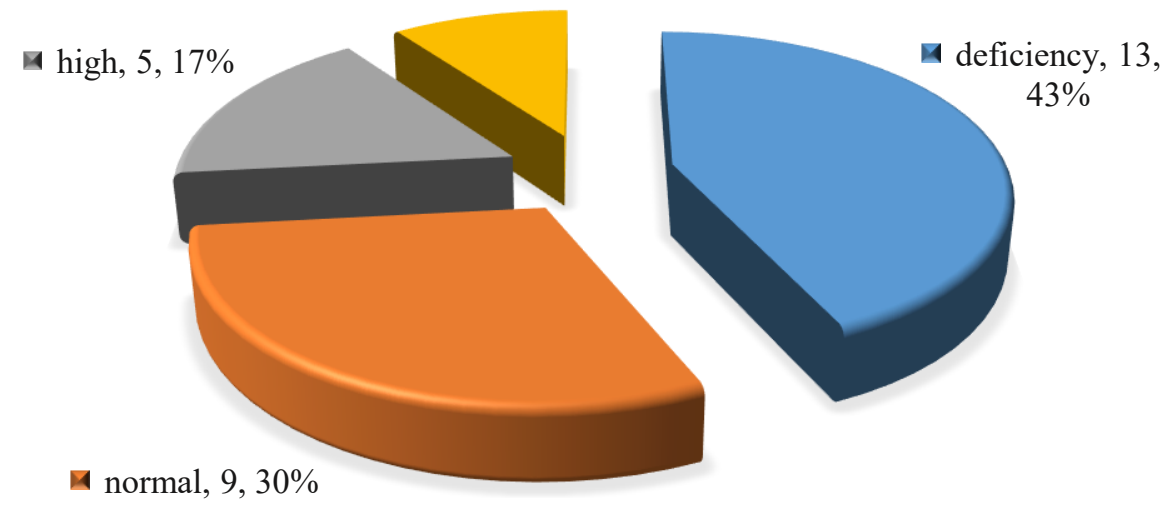

Figure 6. Evaluation of nitrogen content in vegetables.

Between $\mathrm{N}$ content in soil and $\mathrm{N}$ content vegetables there was a good correlation of $R^{2}=0.91$.

\section{REFERENCES}

1. Boink A, Speijers G. Health Effects of Nitrate and Nitrites, A Review. Acta Hortic. 2001;563:29-36

2. Sh. Umar A, Iqbal M. Nitrate accumulation in plants, factors affecting the process, and human health implications. Agron Sustain Dev. 2007;27:45-57.

3. Iammarino M, Di Taranto A, Cristino M. Monitoring of nitrites and nitrate levels in leafy vegetables (spinach and lettuce). J Sci Food Agric. 2014;15:773-8.

4. EFSA Journal, Nitrate in Vegetables, Scientific opinion of the Pannel on Contaminants in the Food Chain, 2008, 689.

5. D. Brkić, J. Bošnir, M. Bevardi, et., al. Nitrate in leafy green vegetables and estimated intake. Afr J Tradit Compl Altern Med. 2017; 14(3): 31-41.

6. Temme EH, van devijvere $\mathrm{S}$, et., al. Average daily nitrate and nitrite intake in the Belgian population older than 15 years. Food Addit Contam Part A Chem Anal Control Expo Risk Assess. 2011;28:1193-204.

7. Lijinsky W, N-Nitroso compounds in the diet. Mutat Res443:129-138 (1999).

8. Knobeloch L, Salna B, Hogan A, Postle J and Anderson H, Blue babies and nitratecontaminated well water. Environ Health Perspect 108:675-678 (2000).

9. Vittozzi L, Toxicology of nitrates and nitrites. Food Addit Contam 9: (1992). 
10. Boink A and Speijers GJA,Health effects of nitrates and nitrites, a review. Acta Hortic 563:29-36 (2001).

11. Norman G, Hord NG, Tang Y, Bryan NS. Food sources of nitrates and nitrites: the physiologic context for potential health benefits. Am J Clin Nutr. 2009;90(1)

12. Speijers GJA, Nitrate, in Toxicological evaluation of certain food additives and contaminants in food, ed by WHO, Food Additives Series 35, Geneva, (1996).

13. P. Santamaria. Nitrate in vegetables: toxicity, content, intake and EC regulation. Sci Food Agric 86:10-17 (2006)

14. Hambridge T, Nitrate and nitrite: intake assessment. WHO Food Additives Series 50 (2003). 